\title{
Using quail waste as an adsorbent on biogas quality
}

\author{
Aurelia Aprilianty,, , Arina Manasikana², Eggi Pur Pinandita ${ }^{3}$, Shafa Fa'izah $^{3}$, \\ Mochammad Junus ${ }^{4}$, and Hary Nugroho ${ }^{4}$ \\ ${ }^{1}$ Undergraduate program of Faculty of Animal Science, Universitas Brawijaya, Malang 65145, East \\ Java, Indonesia \\ ${ }^{2}$ Doctoral program of Faculty of Animal Science, Universitas Brawijaya, Malang 65145, East Java, \\ Indonesia \\ ${ }^{3}$ Magister program of Faculty of Animal Science, Universitas Brawijaya, Malang 65145, East Java, \\ Indonesia \\ ${ }^{4}$ Faculty of Animal Science, Universitas Brawijaya, Malang 65145, East Java, Indonesia
}

\begin{abstract}
The aim of this research is to determine the effect of coconut and mineral waste of quail as adsorbents on the biogas purity. This research was designed to use the Completely Randomized Design (CRD) method with 6 treatments and 4 replications and the significant influence will be tested using Duncan Test. The result form this research showed that the use of coconut waste and mineral waste of quail as adsorbents gives highly significant influence $(\mathrm{P}<0,01)$ to increase the $\mathrm{CH} 4$ gas concentration, highly significant influence $(\mathrm{P}<0,01)$ to decrease $\mathrm{CO}_{2}$ gas concentration, highly significant influence $(\mathrm{P}<0,01)$ to decrease gas pressure and highly significant influence $(\mathrm{P}<0,01)$ to increase gas flow rate on biogas purity. The conclusion of this research is the use of $100 \%$ of activated coal from coconut waste, the use of $50 \%$ of activated coal from coconut waste and $50 \%$ of mineral waste from quail waste as an adsorbent are able to increase the quality of biogas. However, it is lack of effectiveness due to inappropriate application of biogas purification. It is suggested to do physical activation for both adsorbents in order to avoid saturation of the adsorbent so those absorbents be able to adsorb optimally the impurities gases on biogas.
\end{abstract}

\section{Introduction}

Indonesia is one of the countries facing problems related to the availability of fuel as an energy source. This is due to the large dependence of the Indonesian state on fossil fuels, if this problem is not addressed immediately it will lead to a scarcity of energy sources in Indonesia in the future. In addition, the use of fossil fuels as an energy source can lead to an increase in the concentration of greenhouse gases in the atmosphere caused by carbon emissions. Therefore, it is necessary to use alternative energy by utilizing renewable energy or renewable energy sources whose use is intended to reduce the use of fossil fuels. Indonesia is an agricultural country where the majority of the population works in the agricultural and livestock sectors so that the quantity of waste produced from this sector is

\footnotetext{
* Corresponding author: Aureliaaprlnty@student.ub.ac.id
} 
abundant. In otherwise, the provision of feed for animals is a major contributor to land and water use greenhouse gas emission [1]. In line, overfishing and reduction in available land and water resources in huge archipelago island like Indonesia on which crops can be grown has led to an increase in animal industry. [2]

Moreover, it is unfortunate that this waste from the agricultural and livestock sectors is often not utilized and thrown away. According to [3] the presence of animal waste that is wasted on land without the involvement of water will produce types of greenhouse gases such as $\mathrm{CO}_{2}, \mathrm{~N}_{2} \mathrm{O}, \mathrm{NO}_{2}, \mathrm{NO}_{\mathrm{x}}$ and $\mathrm{CH}_{4}$. Then animal waste that is dumped into the waters will produce greenhouse gases such as $\mathrm{CO}_{2}$ and $\mathrm{CH}_{4}$. Therefore, further handling and processing is needed so that waste from this sector does not become a source of environmental pollution. Biogas is a renewable energy, which in the energy production process utilizes non-fossil raw materials such as waste from the agricultural sector, especially livestock. Biogas is the result of anaerobic degradation of organic compounds with the help of methane bacteria which can be a substitute for natural gas and fossil fuels. Biogas contains components such as methane gas $\left(\mathrm{CH}_{4}\right)$, carbon dioxide gas $\left(\mathrm{CO}_{2}\right)$, oxygen gas $\left(\mathrm{O}_{2}\right)$, hydrogen sulfide gas $\left(\mathrm{H}_{2} \mathrm{~S}\right)$, nitrogen gas $(\mathrm{N} 2)$, hydrogen gas $\left(\mathrm{H}_{2}\right)$, ammonia $\left(\mathrm{NH}_{3}\right)$, and gas. carbon monoxide $(\mathrm{CO})$. According to [4] the quality of biogas is determined from the percentage of methane gas $\left(\mathrm{CH}_{4}\right)$ and carbon dioxide gas $\left(\mathrm{CO}_{2}\right)$. Biogas which has a high content of methane $\left(\mathrm{CH}_{4}\right)$ will have a high calorific value, and vice versa if the level of carbon dioxide gas $\left(\mathrm{CO}_{2}\right)$ in biogas is high, it will result in a low calorific value of biogas.

This is confirmed by [5] based on his research, the largest composition of biogas produced from anaerobic fermentation is methane gas $\left(\mathrm{CH}_{4}\right)$ around $54-70 \%$, and carbon dioxide gas $\left(\mathrm{CO}_{2}\right)$ around $27-45 \%$. Therefore, it is necessary to make efforts to reduce the percentage of carbon dioxide $\left(\mathrm{CO}_{2}\right)$ gas content in biogas to improve the combustion quality and biogas calories. Purification of biogas is one way to reduce the levels of impurity gases in biogas such as carbon dioxide gas $\left(\mathrm{CO}_{2}\right)$ and hydrogen sulfide gas $\left(\mathrm{H}_{2} \mathrm{~S}\right)$ which are corrosive, with purification causing the levels of methane gas $\left(\mathrm{CH}_{4}\right)$ in biogas to increase. Based on research [6] purification or purification of biogas aims to increase heat efficiency, increase the amount of methane gas composition between 4-20\% from before and can reduce the content of $\mathrm{CO}_{2}, \mathrm{H}_{2} \mathrm{O}$ and $\mathrm{H}_{2} \mathrm{~S}$. Purification of biogas can be carried out by chemical absorption methods and adsorption on solid surfaces. The adsorption method on solid surfaces is one of the effective methods for adsorbing impurities in biogas [7]. [4] added that one of the adsorbents that can be used in the purification of biogas is charcoal/activated carbon. Besides being easy to obtain, the use of charcoal/activated carbon is widely used because the price is relatively cheap compared to zeolite and chemical adsorbents. Coconut shell waste and quail livestock waste minerals can be used as adsorbents for gas impurities in biogas, so that the resulting biogas contains methane gas $\left(\mathrm{CH}_{4}\right)$ and a higher calorific value. Furthermore, biogas as renewable energy is able to overcome the negative impacts of livestock and fishery waste, so that a clean environment can be realized and can maintain the sustainability of domestic energy sources. According to thus condition the objective of this research to determine the effect of activated carbon and mineral quail waste as adsorbents on the biogas quality.

\section{Materials and methods}

Field research was conducted to determine the manufacture of biogas digester tanks (jurigen), biogas purification equipment, biogas manufacture and the application of various biogas purification treatments. The materials in this study are divided into two, namely the main material is the material observed in the biogas purification process and the supporting material is the material used in the purification process. 
The research equipment included: 1). plastic balloons, 2). buckets, 3). digital scale, 4). Biogas installation from Jurgen with 351 capacity 5). biogas purifier and 6). Stopwatch. While the materials were 1). dairy cattle manure, 2). Octopus waste 3 ). quail manure. 4), well water, 5) activated carbon and 6). Quail minerals. The method used were conducted using completely randomized design. The experiment consisted six treatments and four replicate. The parameters observed were biogas composition before and after purifications; flow rate; and pressure of biogas.

The analysis of variance and Duncan multiple range test were used to analyze the observation results.

\section{Results and discussion}

\subsection{Biogas Content Before Purification}

The results of measuring the content of biogas were using a GC (Gas Chromatography) tool show that before the purification process was carried out, the gas content was detected, namely, methane gas $\left(\mathrm{CH}_{4}\right)$, carbon dioxide gas $\left(\mathrm{CO}_{2}\right)$ and hydrogen gas $\left(\mathrm{H}_{2}\right)$. The measurement results show that the concentration of gas in the biogas before purification has a relatively low $\mathrm{CH}_{4}$ gas level and a high $\mathrm{CO}_{2}$ gas level. The following in Table 1 is the average concentration of gas content in biogas before purification is carried out.

Table 1. Biogas composition before purification

\begin{tabular}{|l|l|}
\hline \multicolumn{1}{|c|}{ Gases } & \multicolumn{1}{c|}{ Average } \\
\hline Methane $\left(\mathrm{CH}_{4}\right)$ & $33.99 \pm 4.41$ \\
\hline Carbon dioxide $\left(\mathrm{CO}_{2}\right)$ & $60.52 \pm 5.45$ \\
\hline Hydrogen $\left(\mathrm{H}_{2}\right)$ & $5.49 \pm 2.49$ \\
\hline
\end{tabular}

Table 1 shows the average level of methane gas $\left(\mathrm{CH}_{4}\right)$ produced in the biogas produced in the jurigen anaerobic digester, which is $33.99 \%$, which is still quite low. While the content of impurity gases such as carbon dioxide gas $\left(\mathrm{CO}_{2}\right)$ has a fairly high content of $60.52 \%$. The results of this biogas measurement show the low quality of the biogas produced in the jurigen anaerobic digester. The factor that causes the low concentration of $\mathrm{CH}_{4}$ gas in the biogas can be caused by the absence of the activity of the bacteria forming the biogas. Methane gas in biogas is a by-product of the anaerobic biological process of methanogenic bacteria. Methanogenic bacteria can carry out the process of producing methane gas if it is supported by optimal environmental conditions for their production activities. The type of organic material used as raw material for the manufacture of biogas sludge and environmental temperature can affect the activity of microorganisms in forming methane gas. Methanogenic bacteria can perform methanogenesis/methane gas formation activity at the highest temperature of \pm 35 -550C [8]. The average temperature for $1-2$ months during the production of biogas in the biodigester from jerry cans is $27.50 \mathrm{C}$, so the activity of methanogenic bacteria in producing methane gas is not optimal. To increase the temperature of the biodigester, it can be put in a thick cardboard or covered with a tarp and an extra heater using a light bulb is used.

The organic material of biogas sludge used in this study was a mixture of quail livestock waste and squid waste with the addition of cow feces as a starter which was fermented using a digester made of plastic jurigen following the digester design of [9] Organic matter 
Quail waste and squid waste are placed in closed jurygen tanks and processed anaerobically for 1-2 months depending on the amount of material added. The advantage of making biogas using this type of digester is that it is easy to apply and the construction cost is cheaper than using other types of digesters. The weakness of this type of digester is that the temperature of the digester is influenced by the ambient temperature so that to achieve the optimal temperature in the formation of methane gas, an extra heater is needed such as a light bulb. Then, this type of digester has the potential for leakage so that the fermentation process does not take place anaerobically which causes the methanogenesis process to be hampered and biogas production decreases.

\subsection{Biogas Content After Purification $\left(\mathrm{CO}_{2}, \mathrm{CH}_{4}, \mathrm{H}_{2}\right)$}

The results of the measurement of the biogas content which consists of the calculation results of the percentage concentrations of $\mathrm{CO}_{2}, \mathrm{CH}_{4}$ and $\mathrm{H}_{2}$ gases. The results of the analysis of variance showed that the treatment using activated carbon adsorbents from coconut shells and minerals from quail livestock waste gave a very significant difference $(\mathrm{P}$ $<0.01$ ) to the content of biogas, namely $\mathrm{CO}_{2}, \mathrm{CH}_{4}$ and $\mathrm{H}_{2}$ gas concentrations. The results of the research showed that the highest to lowest concentrations of $\mathrm{CH}_{4}$ gas were treatments $\mathrm{T} 1, \mathrm{~T} 3, \mathrm{~T} 2, \mathrm{~T} 4, \mathrm{~T} 0$ and $\mathrm{T} 5$, respectively. The average value of $\mathrm{CH}_{4}$ gas concentration in $\mathrm{T} 5$ treatment was $5.13 \pm 0.85 \mathrm{a}$ with $100 \%$ mineral adsorbent from quail livestock waste, the average value of $\mathrm{T} 5$ resulted in the lowest average value of $\mathrm{CH}_{4}$ gas concentration compared to treatments T0, T1, T3, T2 and T4. Meanwhile, the concentration of $\mathrm{CH}_{4}$ gas in T1 treatment with $100 \%$ activated carbon as adsorbent from coconut shell waste resulted in the highest average value of $63.89 \pm 3.80 \mathrm{~d}$. It is suspected that biogas purified with $100 \%$ mineral adsorbent from quail livestock waste (T5) has a mixture of other gases such as $\mathrm{CO}_{2}$ and $\mathrm{H} 2$ gases with higher concentrations than other adsorbent treatments. Figure 1 is a bar chart showing the effect of adsorbent concentration on the biogas content, the diagram shows the $\mathrm{CO}_{2}$ and $\mathrm{H}_{2}$ gas concentrations in the T5 treatment respectively $78.57 \pm 1.141 \mathrm{~d}$ and $16.30 \pm 0.62 \mathrm{c}$.

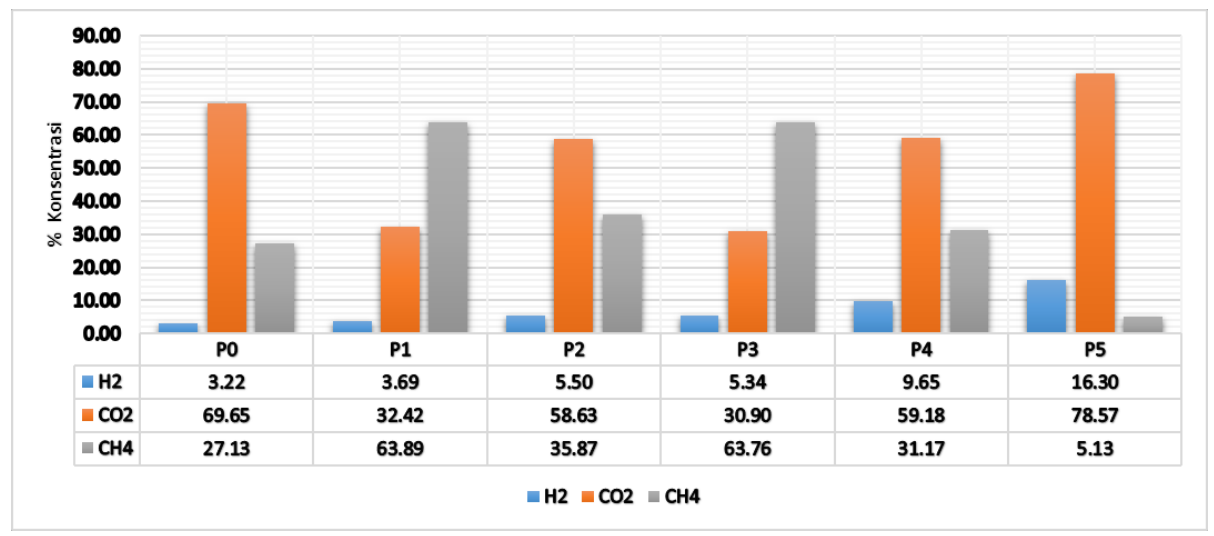

Fig. 1. Effect of adsorbent concentration on biogas content

This is also supported by research conducted by [10] that the production of $\mathrm{CH}_{4}$ gas tends to decrease along with the increase in the amount of Fe (mineral) in the manufacture of bio gas, so the decrease in the concentration of $\mathrm{CH}_{4}$ gas can be associated with an increase in the concentration of $\mathrm{CO}_{2}$ gas produced during the fermentation process. The lowest to highest $\mathrm{CO}_{2}$ gas concentrations were treatments T3, T1, T2, T4 and T5, 
respectively. The average value of $\mathrm{CO}_{2}$ gas concentration in treatment $\mathrm{T} 5$ was $78.57 \pm$ $1.141 \mathrm{~d}$ with $100 \%$ mineral adsorbent from quail livestock waste producing the highest average value compared to treatments $\mathrm{T} 0, \mathrm{~T} 1, \mathrm{~T} 2, \mathrm{~T} 3$ and $\mathrm{T} 4$. The concentration of $\mathrm{CO}_{2}$ gas in treatment $\mathrm{T} 1(32.42 \pm 5.08 \mathrm{a})$ with $100 \%$ activated carbon as adsorbent from coconut shell waste resulted in the lowest average value.

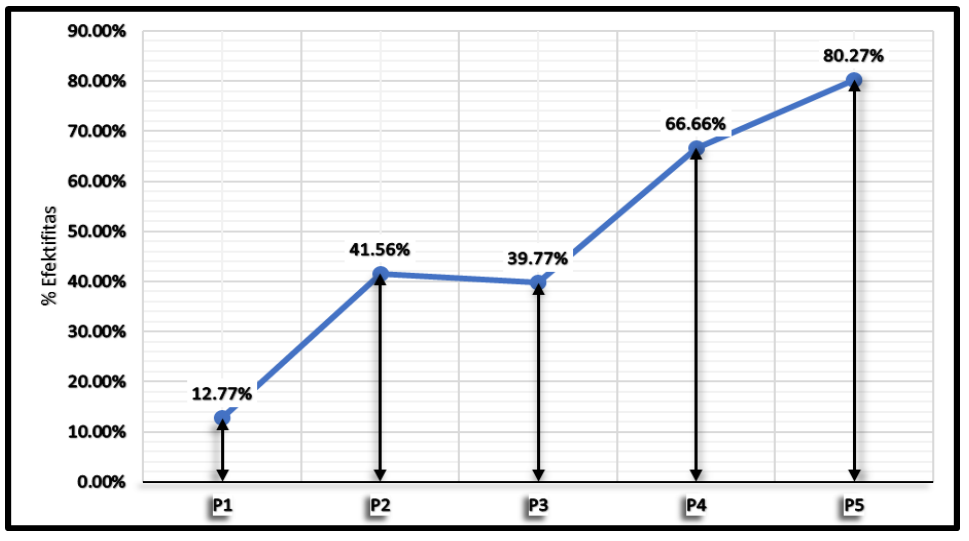

Figure 2. $\mathrm{H}_{2}$ gas concentration improvement chart (\%)

Meanwhile, the concentration of $\mathrm{H}_{2}$ gas in biogas from the lowest to the highest were treatments T0, T1, T2, P3, P4 and T5, respectively. The average value of $\mathrm{H}_{2}$ gas concentration in treatment T5 was $16.30 \pm 0.62 \mathrm{c}$ with $100 \%$ mineral adsorbent from quail livestock waste producing the highest average value compared to treatments T1, T2, T3, T2 and T4. The concentration of $\mathrm{H}_{2}$ gas in the control treatment $\mathrm{T} 0$ was $3.22 \pm 0.139 \mathrm{a}$ which was the control treatment or without the adsorbent treatment resulting in the lowest average value. The data from this study indicate that the increase in the concentration of mineral adsorbents from quail livestock waste is directly proportional to the increase in the concentration of $\mathrm{H}_{2}$ gas in the bio gas content. Therefore, the use of $100 \%$ mineral adsorbent from quail livestock waste was effective in purifying hydrogen gas $\left(\mathrm{H}_{2}\right)$ in bio gas with an increase in $\mathrm{H}_{2}$ gas value of $80.27 \%$ in $\mathrm{T} 5$ treatment (Figure 2). This is supported by research conducted by [11] that the use of $\mathrm{Fe}_{2} \mathrm{O}_{3}$ and $\mathrm{Al}_{2} \mathrm{O}_{3}$ as mineral adsorbents has resulted in $99.8 \%$ purity of hydrogen gas in synthetic biogas. The purity of hydrogen gas occurs due to the decomposition of $\mathrm{CH}_{4}$ gas as described in the thermodynamic equilibrium of the Boundouard reaction. So, it can be assumed that the decrease in the concentration of $\mathrm{CH}_{4}$ gas in the $\mathrm{P} 5$ treatment biogas is caused by the decomposition of $\mathrm{CH}_{4}$ gas into $\mathrm{H}_{2}$ gas. Or caused by other factors such as saturation of the adsorbent used in the purification of bio gas treatment T5 so that the adsorbent is not able to capture $\mathrm{CO}_{2}$ gas as an impurity gas in biogas. This saturation is due to the fullness of the adsorbent cavities by $\mathrm{CO}_{2}$ gas which causes an increase in the $\mathrm{CO}_{2}$ gas concentration in the T5 treatment.

\subsection{Treatment of flow rate and pressure of purification of Biogas}

The test will be carried out of treatment with different amount of carbon and mineral quail waste. The biogas water flow rate and gas pressure the test results after passing through the adsorption process is shown in Table 2. 
Table 2. Water Flow rate and gas pressure after passing through the adsorption process

\begin{tabular}{|l|l|l|}
\hline Treatment & Flow Rate $(\mathrm{mL} / \mathrm{s})$ & \multicolumn{1}{|c|}{ Pressure $(\mathrm{Pa})$} \\
\hline T0 & $2.363^{\mathrm{a}}$ & $99.319^{\mathrm{e}}$ \\
\hline T1 & $2.468^{\mathrm{a}}$ & $93.801^{\mathrm{d}}$ \\
\hline T2 & $11.868^{\mathrm{b}}$ & $29.019^{\mathrm{c}}$ \\
\hline T3 & $15.128^{\mathrm{c}}$ & $21.253^{\mathrm{d}}$ \\
\hline T4 & $19.943^{\mathrm{e}}$ & $5.926^{\mathrm{a}}$ \\
\hline T5 & $19.678^{\mathrm{d}}$ & $6.540^{\mathrm{a}}$ \\
\hline
\end{tabular}

${ }^{\mathrm{a}-}$ values with different superscripts within a column are significantly differences $(\mathrm{P}<0.05)$

The water flow rate and gas pressure are shown in Table 2. The results showed significant differences in water flow rate and gas pressure $(\mathrm{P}<0.05)$. As a result, increase in the water flow rate will decrease gas pressure. The treatments of P2, P3, P4, and P5 showed higher water flow rate than the control treatment (P0). However, P1 treatment had lower water flow rate than the control treatment even it had no significant difference. T5 and T4 had completely high-water flow rate $(19.678-19.943 \mathrm{~mL} / \mathrm{s})$ than the other treatments and the control. The results were similar by [12] the effectiveness of $\mathrm{CO}_{2}$ absorption of biogas increase along with higher biogas pressure and water flow rate. This is because the adsorbent takes more time to absorb the impurity gases in the bio gas, also due to the remodeling process the microbes in the digester are not good. However, this bio gas purification flow rate cannot be an absolute benchmark in determining the quality of bio gas. The length of time required for gas to pass through the adsorbent can be caused by various factors.

On the other hand, there were significant differences among the gas pressure of treatments. However, the gas pressure was 6.540, 5.926, 21.253, 29.019, 93.801, 99.319 for $\mathrm{T} 5, \mathrm{~T} 4, \mathrm{~T} 3, \mathrm{~T} 2$, T1, and $\mathrm{T} 0$ respectively. The treatments of T1, T2, T3, T4, and T5 showed significant differences with lower gas pressure than the control of treatment $(\mathrm{P}<0.05)$. This is because the minerals in quail waste contain calcium $(\mathrm{Ca})$ compounds which have the ability to bind $\mathrm{CO}_{2}$ gas, resulting in an increase in the concentration of $\mathrm{CH}_{4}$ gas which causes an increase in the calorific value of the bio gas. However, in T5 treatment $(100 \%$ minerals from quail excreta) the percentage of pressure drop was lower than in $\mathrm{T} 4$ treatment, this is presumably due to saturation of the adsorbent used. Saturation is caused by the cavities in the adsorbent that have been filled with impurities so that they are no longer able to absorb. The decrease in the value of gas pressure in the bio gas that has gone through the purification process occurs due to the absorption of $\mathrm{CO}_{2}$ gas in the adsorbent. The lower the resulting pressure value, the more $\mathrm{CO}_{2}$ gas is absorbed. Gas pressure has a function to flow gas into the adsorbent tube and into the bio gas sample holder. [12] during the time of gas pressure test in columns adsorbent should be conservation as to not become over-pressured nor pull out (under-pressured). This is caused by anaerobic fermentation process is very sensitive to changes in temperature and biogas production will decrease rapidly due to changes in temperature reactor inside reactor. 


\section{Conclusion}

Results from this study proved that various treatments with different amount of carbon and mineral quail waste had high of water flow rate and less gas pressure than the control treatment. Moreover, the high amount of carbon and minerals quail waste had the best result. These findings indicated that $\mathrm{P} 4$ had greatest effectiveness in water flow rate and gas pressure. 1. Efforts to purify bio gas with the best quality can be carried out using an adsorbent of $100 \%$ activated carbon from coconut shell waste (P1) and using an adsorbent of $50 \%$ activated carbon from coconut shell waste and 50\% minerals from quail livestock waste (P3). The use of $100 \% \mathrm{Ca}^{2+}$ mineral adsorbent in quail excreta to purify bio gas is considered ineffective because it is not good at applying adsorbents during bio gas purification, such as not having physical activation such as aerating and drying after using the adsorbent so that this adsorbent treatment does not can show an increasing trend in the concentration of $\mathrm{CH}_{4}$ gas and a decreasing trend in the concentration of $\mathrm{CO}_{2}$ gas in the purified biogas.

It to be recommend the use of both types of adsorbent needs to be considered again, especially regarding the homogeneity of the adsorbent content used so that it has the same adsorption ability. It is necessary to carry out a physical activation process first after using the two adsorbents so that the effectiveness of $\mathrm{CO}_{2}$ gas absorption on the two adsorbents can take place optimally.

\section{References}

1. D. N. Adli, LRRD, 33, 94 (2021)

2. O. Sjofjan, D.N. Adli, R. P. Harahap, A. Jayanegara, D. T. Utama, A. P. Seruni, F1000 Research, 10, 183 (2021)

3. M. Junus, SAADC, 1 (2015)

4. N. Hamidi, Wardana, D. Widhiyanuriyawan, Jurnal Rekayasa Mesin, 2, 227-231 (2011)

5. A. Yamliha, B. D. Agro, W. A. Nugroho, Jurnal Bioproses Komoditas Tropis, 1, 67-72 (2013)

6. S. Wahyudi, M. Arif, N. A. Hidayati, Rekayasa Mesin, 11(2020)

7. D. Widhiyanuriyawan, N. Hamidi, C. Trimandoko, Jurnal Rekayasa Mesin, 5(2014)

8. M. Junus, F. Jaya, Ustadi, M. P. Kurniawan, Y. A. Romadhon, International Journal of Research-Granthaalayah, 9(2021),

9. R. Jammet, Methane Production guide- how to make biogas, (2012)

10. I. Suraya, Tiarasti, H. Irvan, B. Trisakti. Jurnal Teknik Kimia USU, 1(2012)

11. S. Bock, R. Zacharias, V. Hacker. Royal Society of Chemistry, 9(2019)

12. T. M. Gantina, P. Iriani P, Maridjo, C. K. Wachjoe. J. Phys. Conf. Ser., 012011 (2020) 